\title{
Effect of combination of electrolyte and buffer on electrical production in fuel cell microbial system with Pseudomonas sp. in molasses substrate
}

\author{
Maswati Baharuddin ${ }^{1 *}$, Muh Rajib $^{1}$, Sappewali ${ }^{1}$, and Ummi Zahra ${ }^{1}$ \\ ${ }^{1}$ Faculty of Science and Technology, Universitas Islam Negeri Alauddin Makassar, 92113, Indonesia
}

\begin{abstract}
MFC is a bio-electrochemical system driving an electric current by using high-energy bacteria and oxidants. This research aimed to investigate the effect of electrolyte and buffer on electrical production using Pseudomonas sp. In Molasses substrate. The method in this research was the double compartment that consist of anode and cathode chambers. Both were related by salt bridge. This study showed that the addition of a combination of $\mathrm{KMnO} 4$ electrolyte solution with sodium phosphate buffer solution obtained a maximum potential difference of $0.67 \mathrm{~V}$. The result also revealed that the combination of $\mathrm{KMnO}_{4}$ electrolyte solution with Potassium Phosphate Buffer solution produced a $1.44 \mathrm{~mA}$ maximum current with power density of $660.82 \mathrm{~mW} / \mathrm{m}^{2}$.
\end{abstract}

\section{Introduction}

Energy is one of the important components used in human activities using at human activities. Fossil energy as general source is limited Energy Sources and produced $\mathrm{CO}_{2}$ gas caused global warming, a new energy sources must be developed. Microbial Fuel Cell (MCF) as alternative energy is a bio-electrochemical system utilizing microorganisms to degrade substrates. The energy can be produced from biomass waste that still contains organic compounds such as molasses, bagasse, and water hyacinth. Substrate is one of the important components in the MFC system as an energy source for bacteria that will be converted into electrical energy [1].

Molasses is a syrup by-product of sugar which is unable to crystallize. It consists of 40 $55 \%$ sucrose with a $\mathrm{pH}$ approximately 5.5 - 6.5 and organic acids as a substrate [2]. The use of types condition in the MFC system influenced the production of energy.

There are many MFC studies that combine between electrolyte and buffer solutions in the MFC system $[3,4]$. Purpose of the combination is improving the efficiency of the energy produced [5]. The substrate from tofu waste water with Lactobaccillus bulgarius, showed that $0.2 \mathrm{M} \mathrm{KMnO}_{4}$ solution produced a higher electrical potential of $99.2 \mathrm{mV}$ while $\mathrm{K}_{3} \mathrm{Fe}(\mathrm{CN})_{6} 0.2 \mathrm{M}$ electrolyte solution generated a potential value of $48.6 \mathrm{Mv}$ [6]. The

\footnotetext{
*Corresponding author: bmaswati@gmail.com
} 
combination of a buffer electrolyte solution with the proper concentration of microbes can increase the electrical potential was reported by Fitriani [5].

Based on that, a study was conducted on the Production of Electrical Energy from Molasses Substrates based on Microbial Fuel Cell Technology (MFC) by adding variations in the combination of $\mathrm{KMnO}_{4}$ and $\mathrm{K}_{3} \mathrm{Fe}(\mathrm{CN})_{6}$ electrolyte solutions with sodium phosphate buffer solution and potassium phosphate buffer solution.

\section{Method}

\subsection{Electrode preparation}

The design of compartment consisted of two plastics that were connected by PVC. Top of tube was made space as graphite electrode and copper filament spot, then all the components were glued together. The design of the tool could be seen in Fig. 1.

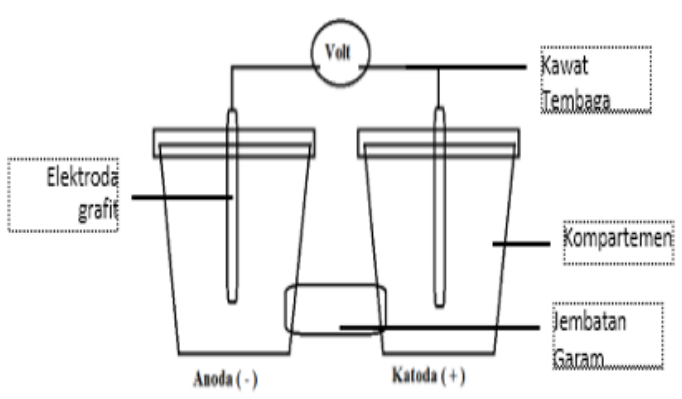

a

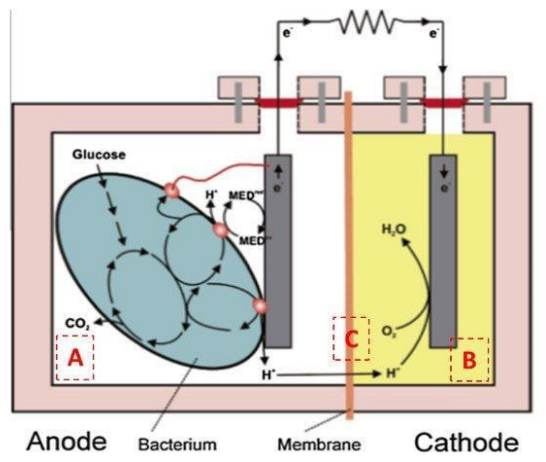

$\mathrm{b}$

Fig. 1. Double compartment design (a), MFC system is consisted anode and cathode (b) $[7,8]$.

Graphite electrode rods was immersed with $1 \mathrm{M}$ HCL for 24 hours then rinsed with distilled water and soaking with $1 \mathrm{M} \mathrm{NaOH}$ for 24 hours, then rinsing again with distilled water.

\subsection{Preparation of electrolyte solution, microorganism, and salt bridge}

The First preparation of electrolyte solution was conducted by diluted 31.6 grams of $\mathrm{KMnO}_{4}$ with $1000 \mathrm{~mL}$ distilled water and 33 grams of solid $\mathrm{K}_{3} \mathrm{Fe}\left(\mathrm{CN}_{6}\right.$ were dissolved with $1000 \mathrm{~mL}$ distilled water [9,6]. The second preparation of microorganism carried out by inserted Isolate Pseudomonas Sp. in NB media into the incubator shaker for 24 hours at $37^{\circ} \mathrm{C}$ with a speed of $125 \mathrm{rpm}$. And the last salt preparation conducted by diluted 5 grams agar in $100 \mathrm{ml}$ of distilled water then heated. Furthermore, added 3 grams of $\mathrm{KCl}$ was homogenized and put into a PCV tube [5].

\subsection{MFC experimental}

Molasses substrate was poured into the anode chamber filled with $350 \mathrm{~mL}$ of distilled water. Next attached the chamber cover and connected it to the voltmeter Then, in every 4 hours during 36 hours, the voltage and potential difference were measured. The next step is the 
measurement of 2 types of electrolyte. For KmNO4, Molasses substrate was inserted into the anode chamber as much as $5 \mathrm{ml}$ added $5 \mathrm{ml}$ of Sodium phosphate buffer and $10 \mathrm{ml}$ of isolate microorganisms. $300 \mathrm{ml}$ of $\mathrm{KMnO}_{4}$ was poured to the cathode chamber. Next, the voltage and potential difference generated was measured every 4 hours for 36 hours. Then, the potassium phosphate buffer is replaced. Then for $\mathrm{K}_{3} \mathrm{Fe}(\mathrm{CN})_{6}$ electrolyte Molasses substrate was poured into an anode chamber as much as $300 \mathrm{ml}$ then $5 \mathrm{ml}$ of sodium phosphate buffer and $10 \mathrm{ml}$ of microorganism. $300 \mathrm{ml}$ of $\mathrm{K}_{3} \mathrm{Fe}(\mathrm{CN})_{6}$ was poured into the cathode chamber 6 . After that, the voltage and potential difference generated was measured every 4 hours for 36 hours, then replace the potassium phosphate buffer.

\section{Results and discussion}

The result showed current and potential differences in the molasses substrate when combined with the addition of $\mathrm{KMnO}_{4}$ and $\mathrm{K}_{3} \mathrm{Fe}(\mathrm{CN})_{6}$ electrolytes in the cathode chamber, whereas in the anode chamber variations of sodium phosphate buffer and potassium phosphate buffer were used at $\mathrm{pH}$ 7. The currents generated in the MFC system without the use of electrolyte solutions and buffer materials showed the current data experiencing instability. At the 20-30 hours there was significant increase. This increase occurred due to the exponential phase of bacterial growth.

The energy increased was stable at 4 th hour was obtained maximum potential difference obtained for 36 hours such as 0.48 Volts. Based on studied by Kurniawati [10] using substrate from cow feces with the addition of Pseudomonas Sp, Cellulomonas Sp and Cellvibrio $S p$, bacteria produce a potential difference of $750 \mathrm{mV}$. The results were greater than the research conducted previously, it maintains temperature caused bacteria can grow optimumly and the use of suitable extracts against cellulotic bacteria. Temperature, $\mathrm{pH}$ and types of microorganisms influenced to produce potential differences.

\subsection{Effect of combination of $\mathrm{KMnO}_{4}$ electrolyte solution with sodium phosphate and potassium phosphate buffer}

The measurement of potential differences in the MFC system using Pseudomonas sp with molasses substrate. The variation $\mathrm{KMnO}_{4}$ electrolyte, sodium phosphate and potassium phosphate buffer solutions are shown in Fig. 2.

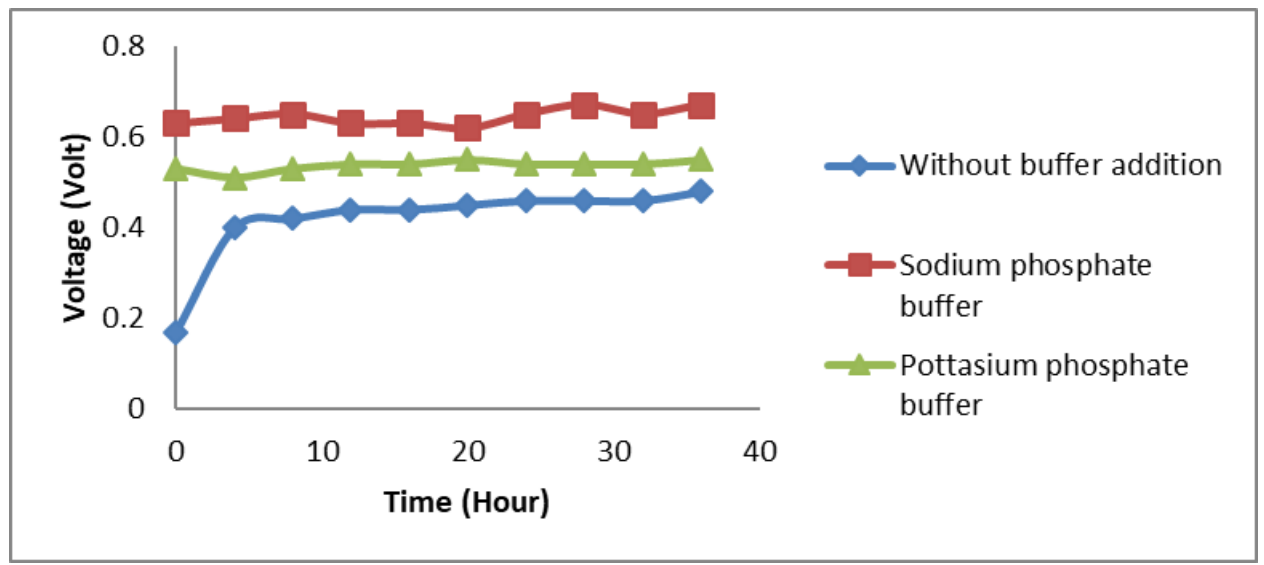

Fig. 2. Potential difference values of molasses substrate with a combination of $\mathrm{KMnO}_{4}$ electrolyte and buffer. 
Fig. 2 revealed that the maximum potential difference is shown in the electrolyte solution with a potassium phosphate buffer of 0.55 volts. Meanwhile in the sodium phosphate buffer of 0.67 volts. the combination of sodium buffer with $\mathrm{KMnO}_{4}$ electrolyte produces a higher potential difference than the combination of potassium buffer solution with $\mathrm{KMnO}_{4}$ electrolyte solution. Based on the research of [11] using S. cerevisiae ATCC 9763 bacteria that produced a maximum potential difference which was $40.67 \mathrm{mV}$.

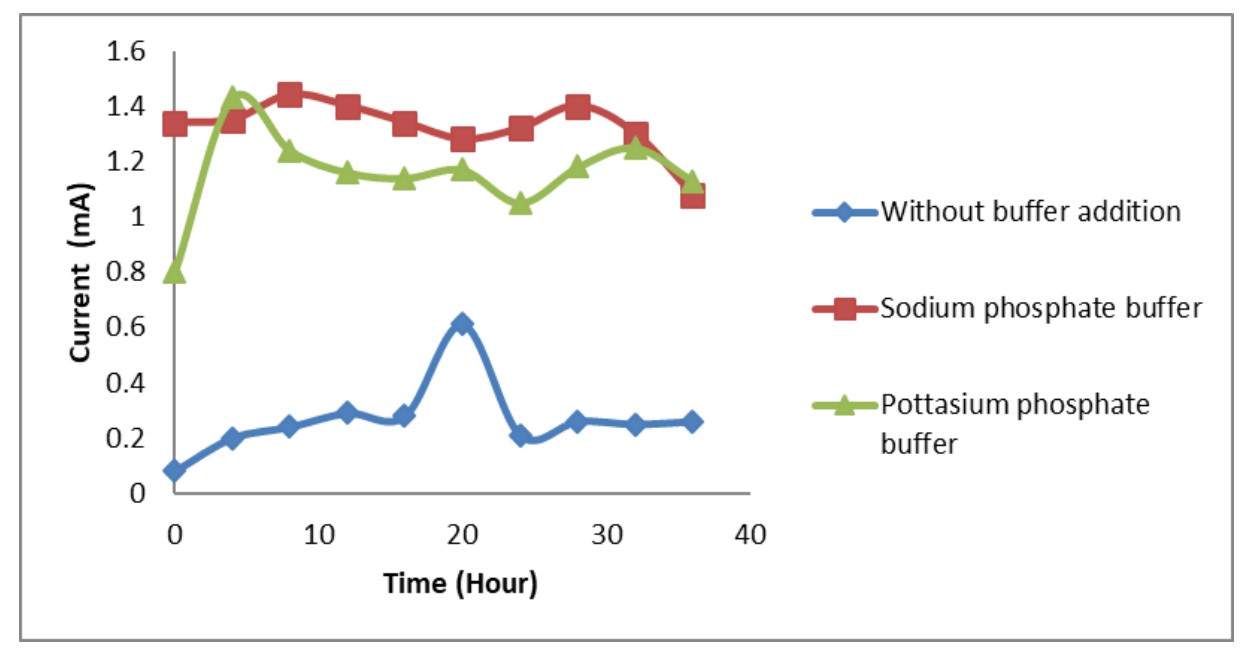

Fig. 3. Molasses substrate flow current value with a combination of $\mathrm{KMnO}_{4}$ electrolyte solution and buffer (Author's Analysis, 2020)

The maximum current obtained was almost equal to $1.43 \mathrm{~mA}$. Based on Pramono and Rani's research [12], which used Eschericia coli bacteria in urine fuel cells, the maximum current is $0.149 \mathrm{~mA}$. This study was obtained high current due to the buffer addition at anode chamber which could maintain the environmental $\mathrm{pH}$, also as a source of nutrients by bacteria produced high [9].

\subsection{Effect of addition of combination of $\mathrm{K}_{3} \mathrm{Fe}(\mathrm{CN})_{6}$ electrolyte solution with potassium phosphate and sodium phosphate buffer subsection two}

Based on Fig. 4 showed that the combination of $\mathrm{K}_{3} \mathrm{Fe}(\mathrm{CN})_{6}$ electrolyte with potassium phosphate buffer produced higher potential difference value than sodium phosphate. The maximum potential difference obtained for the combination of $\mathrm{K}_{3} \mathrm{Fe}(\mathrm{CN})_{6}$ with sodium phosphate buffer solution which was 0.49 volts, potassium phosphate buffer solution produces potential difference which was 0.46 volts. The differences of potential difference were caused by conductivity of $\mathrm{K}+$ and $\mathrm{Na}+$. specific conductivity Ions depending on the number of ions known as molar conductivity. 


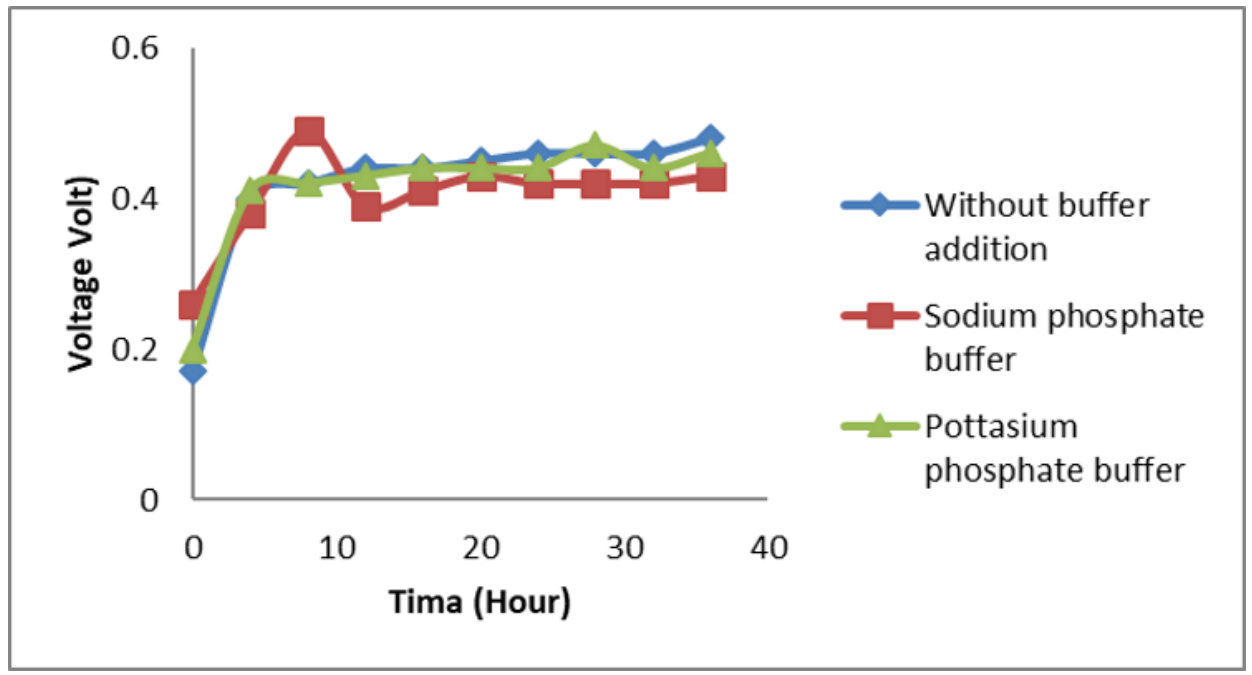

Fig. 4. Potential difference values of molasses substrate with a combination of $\mathrm{K}_{3} \mathrm{Fe}(\mathrm{CN})_{6}$ electrolyte and buffer.

The differences in molar conductivity were related to ion mobility value. If ionic mobility is high caused ion is more active in solution, thus it contributes to conductivity [9]. Fig. 4 showed the increasing of potential difference. It was caused by the sucrose that was directly used by bacteria to produce energy [13]. Based on previous research [14] which used a substrate from septic tank waste water with the bacterium Bacillus suptilis. The reported maximum potential difference generated was $140 \mathrm{mV}$, it showed similarity patterns of graphs of potential difference with the research conducted.

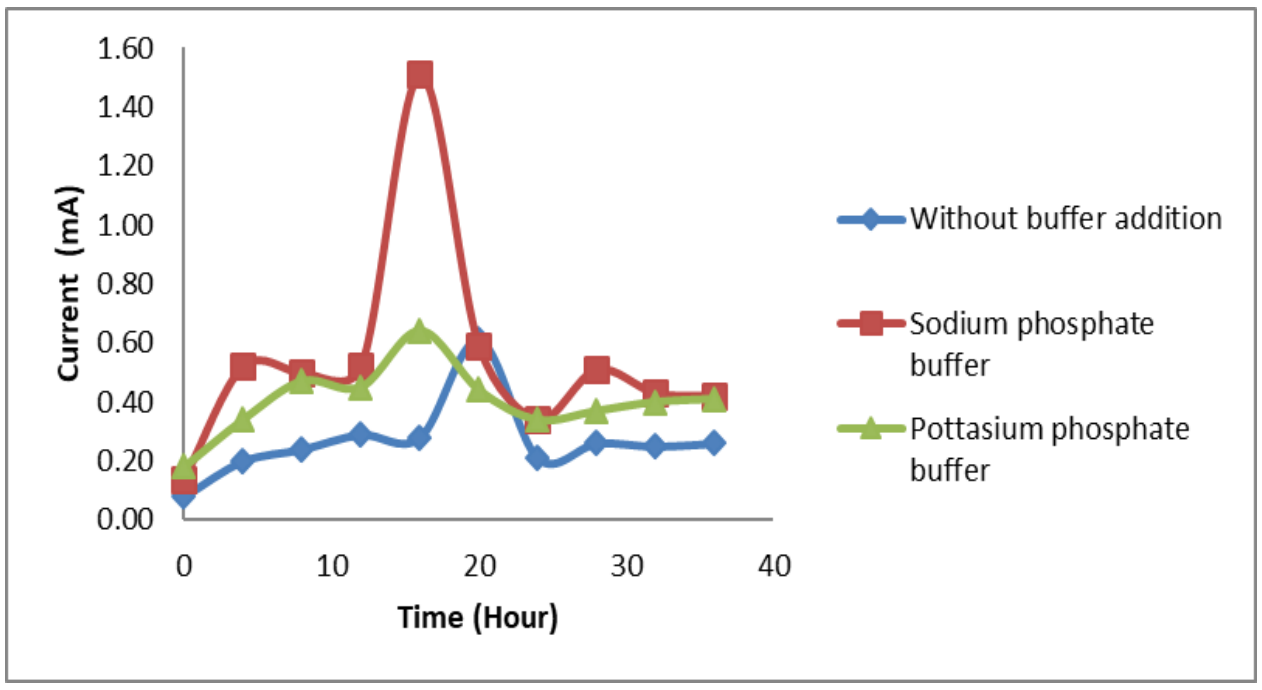

Fig. 5. Molasses substrate flow current value with a combination of $\mathrm{K}_{3} \mathrm{Fe}(\mathrm{CN})_{6}$ electrolyte solution and buffer .

Fig. 5 showed the combination of $\mathrm{K}_{3} \mathrm{Fe}(\mathrm{CN})_{6}$ electrolyte solution with sodium phosphate buffer produced higher average currents than the combination with potassium phosphate buffer. 
The effect of bacterial activity and appropriate $\mathrm{pH}$ conditions. The amount of bacterial activity would influence decompotition of the substrate in the MFC system [15]. The maximum current value obtained is $0.64 \mathrm{~mA}$ for the combination of $\mathrm{K}_{3} \mathrm{Fe}(\mathrm{CN})_{6}$ electrolyte solution with potassium phosphate buffer, whereas the combination of sodium phosphate buffer produces a maximum current value of $1.51 \mathrm{~mA}$.

Addition of sodium phosphate buffer plays as a source of nutrients that needed for bacteria in its growth. As a result, amount of electrons were produced to be transferred to the cathode chamber producing high energy. According to Hayati [16], bacteria have four phases; lag phase, the exponential phase, the stationary phase and the death phase. The lag phase was the time of bacterial collation with the media. The exponential phase was bacteria multiply by dividing cells. The stationary phase was a balanced microbial phase of the number of growth and death. The death phase was the time the nutrients have been reduced from the media that make microbes dying and increase of toxicity.

\subsection{Value of power density $\left(\mathrm{mW} / \mathrm{m}^{2}\right)$}

The result of this study revealed current power and potential differences therefore value of power density can be obtained. Power density was the power per unit surface area of the electrode. The data of study showed that the combination of $\mathrm{KMnO}_{4}$ electrolyte solution with sodium phosphate buffer produces the highest power density value of $660.82 \mathrm{~mW} / \mathrm{m}^{2}$. based on Novitasari's research [17], which used Lactobacillus bulgarius bacteria with the addition of similar electrolyte solution produces a power density of $201.9 \mathrm{~mW} / \mathrm{m}^{2}$ [18]. This value was lower than the research conducted. Pseudomonas $S p$ suitable with the substrate. In addition, electrolyte solution and phosphate buffer greatly influences following the amount of energy produced in the system. The combination of electrolyte solutions with the addition of a phosphate buffer solution at suitable $\mathrm{pH}$ condition influenced energy that produced by bacteria. Besides, it is functioned to maintain environmental conditions, the buffer solution was used as a source of nutrients by bacteria in their metabolic processes.

Research carried out the potential difference value from the combination of $\mathrm{KMnO}_{4}$ electrolyte solution with sodium phosphate buffer solution produces the high potential difference with the maximum potential difference value which was 0.67 volts. The combination of current value of $\mathrm{KMnO}_{4}$ electrolyte solution with sodium phosphate buffer solution produces the high current but the highest is by the combination of $\mathrm{K}_{3} \mathrm{Fe}(\mathrm{CN})_{6}$ solution which was $1.51 \mathrm{~mA}$.

\section{Conclusion}

The Production of Electrical Energy from Molasses Substrates based on Microbial Fuel Cell Technology (MFC) by Combination of $\mathrm{KMnO}_{4}$ electrolyte solution and Sodium Phosphate Buffer solution produces the maximum potential difference and power density $\left(\mathrm{mW} / \mathrm{m}^{2}\right)$ score as much as $660.82 \mathrm{~mW} / \mathrm{m}^{2}$.

\section{References}

1. V.B. Oliveira, M. Simoes, L.F Melo, A.M.F.R. Pinto, Biochemical Engineering Journal 73, 53-65 (2013)

2. Fan.L, Xu. D, Li1. C, Xue S. J. Environ. Stud. 25, 6 (2016)

3. A.J. Slatea, K.A. Whiteheada, D.A.C. Brownsona, C.E. Banks, Renewable and Sustainable Energy Reviews 101, 60-81 (2019)

4. Y. Fan, H. Hu, H. Liu, Environ. Sci. Technol. 42, 6306 (2008) 
5. M. Baharuddin, H. Heriyono, Sappewali, U. Zahra, Prosiding International conference on Science and Teknologi. 2-3 May 2019, Makassar, Indonesia (2019)

6. Muftiani, Kimia Sains dan Aplikasi 21, 1 (2018)

7. B.E. Logan, B. Hamelers, R Rozendal, U. schroder, J. keller, S. Freguia, R. Aelterman, W. Verstraete, Environmental Science \& Technology 14, 17 (2006)

8. M. Rahimnejad, A. Adami, Darvari, A. Zirepour, Alexandria Engineering Journal 54, 745-756 (2015)

9. D. Sari, L. Suyati, D. Widodo, Jurnal Kimia Sains dan Aplikasi 19, 3 (2016)

10. L. Kurniawati, I.G. Made Sanjaya, UNESA Journal of Chemistry 2, 2 (2013)

11. N. Ismawati, Agustina, Aminin, L. Suyati, Jurnal Sains dan Matematika 23, 2 (2015)

12. Pramono, Subur, R. Erika, Jurnal Neutrino 6, 2 (2014)

13. R. Arbianti, T.S. Utami, H. Hermansyah, D. Novitasari, E. Kristin, I. Trisnawati, Makara Seri Teknologi 17, 32-38 (2013)

14. BS Rahardja, P Prayogo, G Mahasri, MD Hardhianto - Jurnal Ilmiah Perikanan dan Kelautan 2, 159-164 (2010)

15. A. Rahmanto, I. Dwi, I.Y.N. Dulm'ad, Jurnal Perikanan Kelautan 7, 157-164 (2016)

16. Hayati, Dini, Noor., Nuryanto, Rahmad.,yati, Linda, Jurnal Sains dan Matematika 23, 3 (2015)

17. Novitasari. Skripsi. Faculty of Engineering Universitas Indonesia, Chemical Engineering Study Program, Depok (2011)

18. A. Gunawardena, S. Fernando, Int. J. Mol. Sci. 9, 1893-1907 (2008) 